\title{
Selected properties of soils located within the depression cone of a planned excavation of the Drzewce open cast pit (central Poland)
}

\author{
Piotr Gajewski ${ }^{1 *}$, Zbigniew Kaczmarek ${ }^{1}$ \\ ${ }^{1}$ Poznań University of Life Sciences, Department of Soil Science and Microbiology, Szydłowska 50, 60-656, Poznań, Poland \\ * dr hab. P. Gajewski, piotr.gajewski@up.poznan.pl, ORCID iD: https://orcid.org/0000-0001-6963-5934
}

\author{
Received: 04.05.2021 \\ Accepted: 12.11.2021 \\ Associated editor: E. Błońska
}

\section{Keywords}

\section{Depression cone}

Drainage degradation

Soil organic matter

Lignite excavation

\begin{abstract}
Open-pit lignite mining requires drainage of the deposit. The depression cone, formed as a result of these activities, has a varied surface and depth, and these features are shaped primarily by the geological structure and by the thickness of the caprock layer. In some of the areas covered by the depression cone, soil productivity may deteriorate, and a related yield reduction may occur, providing the basis for the payment of applied compensations for the owners of such areas. The aim of the study was to assess the condition of selected soils in the vicinity of the planned excavation (Field B) of the Drzewce lignite open pit mine (central Poland). Six profiles were excavated in organic and mineral-organic soils. The locations of the test points were chosen to represent soils that meet the criteria of habitats prone to drainage degradation. The morphological structure of the studied soils and their analysed properties indicate that they have already been drained (probably due to the influence of climate and cultivation), but does not exclude the possible acceleration and enhancement of this process by the commencement of mining activities. For most of the analysed features, a high correlation between their value and organic matter content was observed. Given that the possible commencement of opencast mining operations may significantly accelerate and enhance the already initiated mursh-forming process, it is reasonable to conduct systematic research at the measuring points proposed in the study.
\end{abstract}

\section{Introduction}

Open-pit lignite mining requires drainage of the deposit (Rząsa et al., 1999; Panilas et al., 2008). The depression cone, formed as a result of these activities, has a varied surface and depth, and these features are shaped primarily by the geological structure and by the thickness of the caprock layer (Rząsa et al., 1999). The resulting hydrological transformations are often largescale, sometimes reaching an area of several hundred square kilometres (Panilas et al., 2008; Biemelt et al., 2011). In some of the areas covered by the depression cone, soil productivity may deteriorate, and a related yield reduction may occur, providing the basis for the payment of applied compensations for the owners of such areas. Often, it is necessary to change the land utilisation, for example, by renovation of the meadow sward, and in some cases by the elimination of grassland (Rząsa et al., 1999; Uzarowicz et al., 2014). Rząsa et al. (1999) believe that the reduction in soil productivity occurs primarily in organic hydrogenic soils, and that mineral soils are much less prone. Several decades of field and laboratory experience of the Department of Soil Science and Land Protection of the University of Life Sciences in Poznań shows that the impact of the depression cone on the properties and potential productivity of the soils within its range is a complex issue (Rząsa et al., 1999). Its assessment requires detailed, interdisciplinary expert opinions to evaluate the geobotanical state of the areas at risk of drainage (Mocek et al., 2004). A very important part of them are cyclical (usually monthly) measurements of the level of soil groundwater level, and on this basis, the determination of soil water regime type and systematic phytosociological assessment of the habitats covered by the research. The above-mentioned parameters provide key information that is used to infer the impact of the excavation operation on the surrounding areas. Such tests should be carried out in stages: before the launch of the drainage barrier, during the exploitation of the deposit, as well as after backfilling of the pit, so that it is possible to reliably assess the impact of the pit on the properties of adjacent soils and their potential productivity (Owczarzak et al., 2008). The aim of the study was to assess the condition of selected soils in the vicinity of the planned excavation (Field B) of the Drzewce lignite open pit mine, PAK KWB Konin (central Poland).

The results presented in the paper are part of an interdisciplinary scientific study. Over a dozen or so years, they will help to assess whether and to what extent Field B of the Drzewce open pit will affect the properties of the neighbouring soils. 


\section{Materials and methods}

Field research was carried out during the 2017 growing season before the implementation of a drainage barrier around the pit. Based on soil-agricultural maps (scale: 1:5000) and soil drillings, several research points were selected in which soil profiles were made. Among them, six most characteristic locations were selected with distinctive soil genesis and land use type. The research points were selected to represent hydrogenic habitats that may be subject to mine drainage degradation (Rząsa et al., 1999). The soil profiles were located in two communes in the Konin County: Sompolno (profiles 1, 2, 3, 4 and 5) and Rychwał (profile 6; Fig. 1). At these locations, the soil-ground water level is systematically checked, and on the basis of these data, soil wa- ter regimes types were determined in the analysed soils. During field studies, taxonomic and soil suitability classifications of the analysed soils were carried out.

Disturbed and intact samples $\left(\mathrm{V}=100 \mathrm{~cm}^{3}\right)$ were collected from the individual genetic soil horizons. The collected material was used to analyse the following soil properties: texture of the mineral horizons, using Cassagrande method in the modification by Prószyński (Mocek and Drzymała, 2010); particle density (PD) in the mineral horizons using the pycnometer method (Blake and Hartge,1986), and with the Zawadzki formula (Okruszko, 1971) in the organic and mineral-organic horizons; bulk density (BD), using metal cylinders of known volume (100 $\mathrm{cm}^{3}$ volume); total porosity (TP) was calculated on the basis of the determinations of particle density and bulk density (Mocek

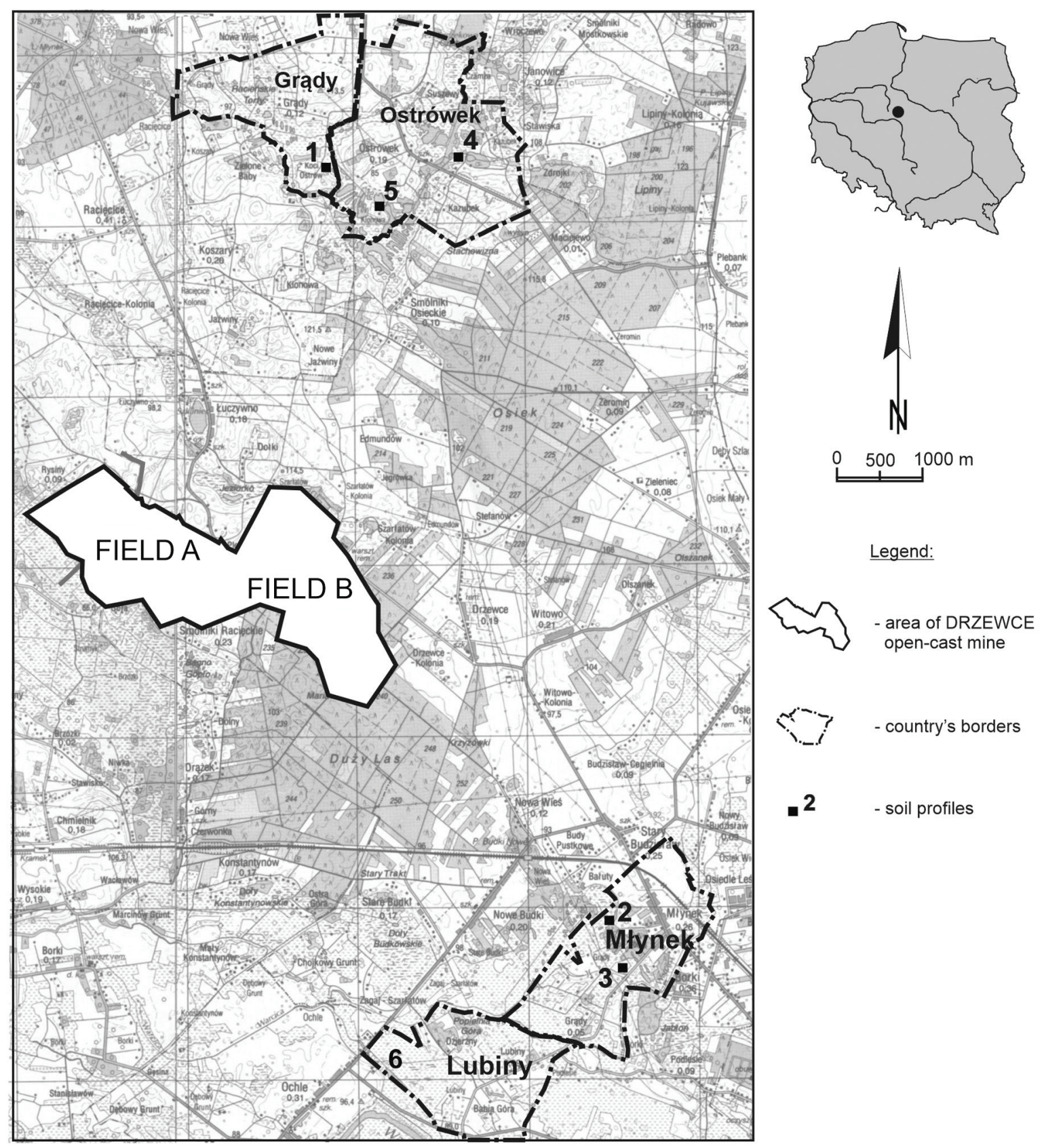

Fig. 1. Location of examined points 
and Drzymała, 2010); drainage porosity (DP) was determined as the difference between total porosity and the moisture content that corresponds to field capacity (indicated at $-10 \mathrm{kPa}$ potential), which is a corresponding value at $\mathrm{pF}=2.0$; organic matter content (OMC), by placing samples in a muffle furnace at $550^{\circ} \mathrm{C}$ (Grimshaw et al., 1989); maximum hygroscopicity ( $\mathrm{MH}$ - moisture content at $\mathrm{pF}$ 4.5) was determined in a vacuum chamber at $0.8 \mathrm{~atm}$. with a potassium sulphate $\left(\mathrm{K}_{2} \mathrm{SO}_{4}\right)$ saturated solution (Mocek and Drzymała, 2010); soil water potential using the Richards pressure chamber method (Klute, 1986); total available water (TAW) and readily available water (RAW) were calculated on the basis of pF determinations (Mocek and Drzymała, 2010) and saturated hydraulic conductivity (Ks) with determined by the constant pressure drop method (Klute and Dirksen, 1986).

A total of 115 intact samples (five from each genetic soil horizon) and 23 disturbed samples were collected. All results presented here are the mean value of five replications. Morphological structure and taxonomic classification were described in accordance with the Systematics of Polish Soils (SgP, 2019) and FAO-WRB (IUSS Working Group WRB, 2015). The Spearman rank correlation coefficients were calculated between OMC and selected soil properties, using a 0.05 significance level.

\section{Results and discussion}

Among the studied habitats, profiles 1, 3 and 4 represented the sapric murshic soils subtype (Murshic Sapric Histosols), profile 5 represented murshic peat soils (Murshic Histosols), and profiles 2 and 6 were typical semimurshic soils (Mollic Gleysols Arenic) (IUSS Working Group WRB, 2015; SgP, 2019). The epipedons of all the examined soils exhibited features of the mursh-forming process; they were composed of mursh in the profiles of the sapric murshic soils and murshic peat soils, and were composed of semi-murshic deposits in the soils of the semimurshic soils. The epipedons of soil profiles 1, 3, 4 and 5 were characterised by a strong granular structure, and the epipedons in soil profiles 2 and 6 were characterised by a moderate granular structure. In the case of organic soils, strongly decomposed peats (sapric) with an amorphous structure were deposited under the epipedons. The mineral substrate, most often sand (Soil Survey Division Staff, 1993; PTG, 2009), lay at a depth of 82-135 $\mathrm{cm}$; characterised by a single grained structure (Jahn et al., 2006, Table 1). At the time of field research the scope of the Field A depression cone did not cover investigated area (Owczarzak et al., 2018). The presence of murshed epipedons indicates that the an-

Table 1

Selected physical properties of examined soils

\begin{tabular}{|c|c|c|c|c|c|c|c|c|}
\hline \multirow{2}{*}{$\begin{array}{l}\text { Soil } \\
\text { profile }\end{array}$} & \multirow{2}{*}{$\begin{array}{l}\text { Soil } \\
\text { horizon }\end{array}$} & \multirow{2}{*}{$\begin{array}{l}\text { Depth } \\
\text { [cm] }\end{array}$} & \multirow{2}{*}{$\begin{array}{l}\text { Organic matter } \\
\text { content } \\
{[\%]}\end{array}$} & \multirow{2}{*}{$\begin{array}{l}\text { Particle } \\
\text { density } \\
{\left[\mathrm{Mg} \mathrm{m}^{-3}\right]}\end{array}$} & \multirow{2}{*}{$\begin{array}{l}\text { Bulk } \\
\text { density } \\
{\left[\mathrm{Mg} \mathrm{m}^{-3}\right]}\end{array}$} & \multirow{2}{*}{$\begin{array}{l}\text { Total } \\
\text { porosity } \\
{[\% \mathrm{v} / \mathrm{v}]}\end{array}$} & \multicolumn{2}{|c|}{ Texture class acc. to: } \\
\hline & & & & & & & PTG 2008 & USDA \\
\hline \multirow[t]{4}{*}{1} & M & $0-32$ & 50.7 & 1.99 & 0.45 & 77.4 & n.d. & n.d. \\
\hline & Oa1 & $32-71$ & 84.2 & 1.62 & 0.39 & 75.9 & n.d. & n.d. \\
\hline & $\mathrm{Oa} 2$ & $71-130$ & 85.5 & 1.61 & 0.31 & 80.8 & n.d. & n.d. \\
\hline & Cgg & $130-200$ & n.d. & 2.65 & 1.65 & 37.7 & $\mathrm{pl}$ & $\mathrm{S}$ \\
\hline \multirow[t]{4}{*}{2} & $\mathrm{Au}$ & $0-31$ & 15.6 & 2.38 & 0.92 & 61.3 & n.d & n.d. \\
\hline & $\mathrm{AC}$ & $31-46$ & 2.10 & 2.53 & 1.57 & 37.9 & n.d. & n.d. \\
\hline & $\mathrm{C} 1$ & $46-67$ & n.d. & 2.65 & 1.61 & 39.3 & $\mathrm{pl}$ & $\mathrm{S}$ \\
\hline & Cgg2 & $67-150$ & n.d. & 2.66 & 1.65 & 38.0 & $\mathrm{pl}$ & $\mathrm{S}$ \\
\hline \multirow[t]{3}{*}{3} & $\mathrm{M}$ & $0-33$ & 31.8 & 2.20 & 0.48 & 78.2 & n.d. & n.d. \\
\hline & $\mathrm{Oa}$ & 33-135 & 22.8 & 2.30 & 0.81 & 64.8 & n.d. & n.d. \\
\hline & Cgg & $135-200$ & n.d. & 2.65 & 1.61 & 39.3 & $\mathrm{pl}$ & $\mathrm{S}$ \\
\hline \multirow[t]{4}{*}{4} & $\mathrm{M}$ & $0-32$ & 25.4 & 2.27 & 0.62 & 72.7 & n.d. & n.d. \\
\hline & Oa1 & $32-57$ & 82.0 & 1.65 & 0.27 & 83.6 & n.d. & n.d. \\
\hline & Oa2 & 57-105 & 85.6 & 1.61 & 0.22 & 86.3 & n.d. & n.d. \\
\hline & Cgg & $105-152$ & n.d. & 2.65 & 1.54 & 41.9 & $\mathrm{pl}$ & $\mathrm{S}$ \\
\hline \multirow[t]{4}{*}{5} & $\mathrm{M}$ & $0-27$ & 36.5 & 2.15 & 0.49 & 77.2 & n.d. & n.d. \\
\hline & Oa1 & $27-64$ & 75.6 & 1.72 & 0.38 & 77.9 & n.d. & n.d. \\
\hline & $\mathrm{Oa} 2$ & $64-82$ & 71.4 & 1.77 & 0.32 & 81.9 & n.d. & n.d. \\
\hline & Cgg & $82-150$ & n.d. & 2.65 & 1.57 & 40.8 & $\mathrm{pl}$ & $\mathrm{S}$ \\
\hline \multirow[t]{4}{*}{6} & $\mathrm{Au}$ & $0-43$ & 13.8 & 2.40 & 1.17 & 51.3 & n.d. & n.d. \\
\hline & $\mathrm{C} 1$ & $43-58$ & n.d. & 2.64 & 1.54 & 41.7 & $\mathrm{pl}$ & $\mathrm{S}$ \\
\hline & Cgg2 & $58-74$ & n.d. & 2.65 & 1.68 & 36.6 & pyi & $\mathrm{SiC}$ \\
\hline & Cgg3 & $74-102$ & n.d. & 2.65 & 1.72 & 35.1 & $\mathrm{pl}$ & $\mathrm{S}$ \\
\hline
\end{tabular}

Explanation: n.d. - not determined; pl - piasek luźny; pyi - pył ilasty; S - sand; SiC - silty clay 
alysed area was not subject (at the time of the field survey) to anthropopressure from mining operations; an important premise that indicates that the drainage process in the analysed habitats was initiated by other unfavourable changes in the water balance. During the field work, the soil-ground water level was also determined. At the analysed points, these measurements were carried out systematically over a period of 12 months, so that it was possible to determine the soil water regime types present there. According to the division proposed by Rząsa et al. (1999), the soil-ground water at the site was at levels that permitted the classification of the studied soils into the following types of soil water regime: profiles 1, 2, 3, 4 and 6 as an alternate water regime, and profile 5 as a groundwater regime. According to the guidelines presented in Rząsa et al. (1999), these areas may be subject to drainage degradation, and if included in the depression cone range (lowering the soil-ground water level), it could potentially accelerate and intensify the already initiated decomposition of organic matter. Previous research around other lignite pits have shown that only changes of a few dozen centimetres or more in the soil-ground water level suggest that they are caused by the activities of the excavation. Smaller fluctuations most often result from seasonal changes that result from climatic conditions, e.g. precipitation, temperature, evaporation (Owczarzak et al., 2017). Therefore, if there is a rapid decrease in the soil-ground water level after the implementation of the mine drainage barrier, this will indicate that the mine is the cause of this change (see Rząsa et al., 1999). During the research period, all the analysed habitats were used as grassland. Their suitability classification and complexes of agricultural suitability were as follows: profiles 1, 3 and 4 were assessed to be soil quality class IV and agricultural suitability complex $2 \mathrm{z}$, and profiles 2 and 5 were assessed to be soil quality class $\mathrm{V}$ and agricultural suitability complex $3 z$.

Organic matter in hydrogenic soils plays a key role in shaping their physical, water and chemical properties. At the same time, its quality and balance in the soil are dictated by environmental conditions and anthropogenic activity, e.g. agriculture, open-pit mining of various raw materials (Kalisz et al., 2010; Turbiak and Miatkowski, 2016; Glina et al., 2019; Wiesmeier et al., 2019). Glina et al. (2019) reported a significant loss of organic matter caused by the activity of a lignite open pit mine, and also reported changes in soil morphology in the form of a decrease in the thickness of the organic horizon. Similarly, Turbiak and Miatkowski (2016) associated the rate of decrease in OMC with the dehydration of hydrological habitats, and found more than a twofold increase in the rate of mineralization due to the deep drainage of the areas covered by the depression cone of the
"Bełchatów" lignite coal mine. Moreover, when determining the loss of organic matter, long-term and multiple measurements of its content and the thickness of the organic layer should be made (Turbiak and Miatkowski, 2016). The above-described organic matter transformations are of interest to environmental research, as they may contribute to the intensification of climate change (Lorenz et al., 2019).

The content of organic matter in the epipedons of the studied soils ranged from $13.8 \%$ to $50.7 \%$ (profiles 6 and 1; Table 1). In peats it ranged from $22.8 \%$ to $85.6 \%$ (Oa, profile 3; Oa2, profile 4). A clear horizontal differentiation in OMC between epiand endopedons was the result of the mursh-forming process that is taking place in the upper horizons of the studied soils, the key part of which is the loss of organic matter. Similar OMC levels and comparable differentiation between the epi- and endopedons of the organic forms were found by Liu et al. (2016), while Reeding and Devito (2006) found significantly higher values in organic soils. Statistical analysis revealed the clear influence of OMC on most of the tested parameters. The strongest correlations are presented in Table 2 . All the presented correlation coefficients were statistically significant.

Particle density (PD) in organic soils is shaped by OMC (Ilnicki, 2002). Those parameters are related because PD was calculated basing on the OMC using linear regression. This connection also applies in part to TP, because when calculating it the authors used particulate density and also DP (drainage porosity). In the epipedons of the analysed soils, this property ranged from 1.99 to $2.40 \mathrm{Mg} \mathrm{m}^{-3}$ (profiles 1 and 6; Table 1). In the peats underlying the surface mursh horizons, PD was usually lower: from 1.61 (Oa2, profile 1; Oa2, profile 4) to $2.30 \mathrm{Mg} \mathrm{m}^{-3}$ (Oa, profile 3), which allowed to classify them as muddy depositions (Okruszko, 1981). Similar values were found by Alberski et al. (2012), although significantly lower values (1.43-1.58 $\mathrm{Mg} \mathrm{m}^{-3}$ ) were found in the peats by Redding and Devito (2006). The components analysed by the aforementioned researchers were characterised by a very high (approx. 90\%) OMC. The variability of PD in hydrogenic soils was also analysed by Sammel et al. (2008), who noted that, as the degree of decomposition increased, the observed PD levels increased. Similar relationships in organic soils were also observed by Glina et al. (2013), who reported a large PD differentiation in their soils, linking it with the silting degree of individual soil horizons and with OMC within them. A similar finding was made by Oleszczuk et al. (2009). Some authors, such as Kechavarzi et al. (2010) and Redding and Devito (2006) have reported that PD in the peats studied by them, increased in conjunction with decomposition rates. Some authors (e.g. Rühlmann et al., 2006) have pointed out that the influence

Table 2

Spearman rank correlation coefficients among selected soil characteristics and organic matter content

\begin{tabular}{lllllllll}
\hline $\begin{array}{l}\text { Spearman } \\
\text { cofficient }\end{array}$ & BD & FC & RF & WP & MH & RAW & TAW & Ks \\
\cline { 2 - 8 } & -0.96 & 0.84 & 0.86 & 0.50 & 0.72 & 0.41 & 0.82 & -0.54 \\
\hline
\end{tabular}

Explanation: all of the presented values were significant at 0.05 level

BD - bulk density; FC - field capacity (pF 2.0); RF - refill point (pF 3.7); WP - wilting point (pF 4.2);

$\mathrm{MH}$ - maximum hygroscopicity (pF 4.5); RAW - readily available water (FC - RF); TAW - total available water (FC-WP);

Ks - saturated hydraulic conductivity 
of organic matter on PD occurs on two levels: as a direct "mass effect" (OMC in the soil), and as the impact of the quality of the organic matter (difference in PD of the individual organic components).

In the context of drainage degradation of soils developed from hydrogenic rocks, BD and TP are important properties. Typically, both features change adversely with progressive drainage, thus indicating the degree of transformation (e.g. Ilnicki, 2002), which is also confirmed by other authors who have investigated mining anthropogenic pressures (Glina et al., 2016), and agricultural pressures (Kalisz et al., 2015). Work by Glina et al. (2019) drew attention to the often overlooked, and difficult to unambiguously assess, impact of natural climate change, e.g. reduced precipitation inputs across years. Therefore, the variability of these features is a very complex, multidimensional issue, and thus is difficult to assess reliably and unambiguously.

In the epipedons, BD in the investigated soils ranged from $0.45 \mathrm{Mg} \mathrm{m}^{-3}$ (profile 1) to $1.17 \mathrm{Mg} \mathrm{m}^{-3}$ (profile 6; Table 1). In the organic endopedons, this feature ranged from $0.22 \mathrm{Mg} \mathrm{m}^{-3}$ to $0.81 \mathrm{Mg} \mathrm{m}^{-3}$ in the Oa2 (profile 4) and Oa (profile 3) horizons respectively. In the mineral horizons, which constituted the subsoil of the analysed soils, the distribution of BD values in the soil was narrow and ranged from 1.54 to $1.72 \mathrm{Mg} \mathrm{m}^{-3}$, and these values were typical of formations with a similar origin and texture (Rząsa et al., 1999). The increase in BD in drained hydrogenic habitats has been noted, among others, by Holden et al. (2011), who found a slight (statistically insignificant) increase in the BD values of peats horizons (sampled at a depth of $40 \mathrm{~cm}$ ) in drained hydrogenic habitats. However, a similar, but statistically significant, direction of change was observed in the upper horizons. Kellner and Halldin (2002) also observed cyclical changes in BD in response to the fluctuating height of the soil-ground water level. The authors called these processes "mire breathing" and reported that a 5-fold increase in BD in endopedons can occur. Kennedy and Price (2005) also reported on the seasonal changes in BD of hydrogenic deposits and pointed out the danger of losing the self-regulating ability by peatlands as a result of long-term drainage. This has been confirmed by Lipka et al. (2017), who emphasised that the increase in peat density occurs simultaneously with the loss of peat mass, which in turn leads to the disappearance of these habitats. Sammel et al. (2008) emphasised the strong relationship between OMC and BD in post-murshic horizons, where the lowest BD values were observed in the horizons with the highest OMC. The performed statistical analysis showed a very high and negative correlation between OMC and BD (Table 2). Similar relationships were noted by Bruland et al. (2004) and Ajibola et. al (2018).

The evaluation of the drainage effect of opencast mining on the physical properties of soils requires TP analyses. This feature largely determines the susceptibility of soils to drainage, and its variability usually accompanies the processes of drainage degradation. Such conclusions have been reached, among others, by Kechavarzi et al. (2010), who reported unfavourable changes in the structure of anthropogenically drained peats, which resulted in a decrease in their moisture retention capacity. This finding is supported by Schwärzel et al. (2002) who reported that the progressive decomposition of organic matter leads to a decrease in TP and an increase in BD. Both changes are most often associated with a simultaneous decrease in the content of organic matter, loss of its thickness, which in some cases can occur over a short time period - serval dozen years (Rząsa et al., 1999). Berglund (2008) has suggested that a 1-m layer of peat may disappear 50 years after dehydration, while smaller (usually several centimetres) loss of thickness in the organic layers were found by Glina et al. (2019) over a 10-year period. The latter study analysed the loss of organic carbon stock in soils subjected to (a) agricultural anthropopressure, and (b) anthropopressure resulting from the activity of lignite exposure. Berglund and Berglund (2011) analysed the properties of two peatlands that had been drained for decades and noted that the decomposition of organic matter was clearly visible in both habitats, especially in the upper horizons, as was an increase in BD and a decrease in TP (by up to 20\%) in comparison to the peat lying beneath them.

In the murshed epipedons, TP ranged from $51.3 \% \mathrm{v} / \mathrm{v}$ (profile 6) to $78.2 \% \mathrm{v} / \mathrm{v}$. (profile 3), and from $64.8 \% \mathrm{v} / \mathrm{v}$ (Oa, profile 3 ) to $86.3 \% \mathrm{v} / \mathrm{v}$. (Oa2, profile 4 ) in the endopedons composed of peat horizons. In the mineral substrate, TP ranged from 35.1 to $41.9 \% \mathrm{v} / \mathrm{v}$. (Table 1). Comparable results in soils of similar origin and OMC were obtained by Alberski et al. (2012). Higher TP values were reported for peat horizons by Carey et al. (2007), while Pawluczyk and Alberski (2011) reported the unfavourable effects of the mursh-forming process and organic matter mineralization on $\mathrm{BD}$ and TP values in organic soils.

When discussing the physical properties of soils developed from hydrogenic deposits, and particularly in the context of the drainage degradation of these formations, it is advisable to perform analyses of drainage porosity (DP) and water permeability of the soil, in addition to TP determinations. The relationship between DP and saturated hydraulic conductivity (Ks) and at the same time the possibilities of drainage has been noted (e.g. Spychalski et al., 2007; Carey et al., 2007; Zhang and Schaap, 2019). Hoag and Price (1997) reported the existence of pores that can actively transmit water via "active" pores, and "inactive" pores in the soil that can trap a significant amount of water (e.g. plant cell remains). In the analysed soils, differences in DP between the upper horizons and the peat lying beneath them are clearly visible (Table 3). In the murshed epipedons, DP values ranged from 11.8 (profile 5) to $38.2 \% \mathrm{v} / \mathrm{v}$. (profile 6). In peats horizons, it was usually lower, from 6.6 (Oa1, profile 1) to $19.1 \% \mathrm{v} / \mathrm{v}$. (Oa2, profile 5). The presented results indicate an increase in DP values as a result of the mursh-forming process, which has also been reported by Kamiński (2007) and Wallor et al. (2018), for example. Schindler et al. (2003), claim that the progressive mineralization of organic matter causes a decrease in the macropore content. Interesting observations are presented by Liu et al. (2016), who suggest that an important parameter describing PD (apart from its size) is the distribution of the shapes of the individual pores. The same authors suggest that the proportion of macropores decreases, and the continuity between them disappears along with the progressive degradation of organic matter. Some of the studies cited above, and the results from the study reported here, lead to contradictory conclusions. This confirms the complicated nature of hydrogenic deposits, and the advisability of further research on the relationships discussed above. 
Table 3

Saturated hydraulic conductivity of examined soils

\begin{tabular}{|c|c|c|c|c|c|}
\hline $\begin{array}{l}\text { Soil } \\
\text { profile }\end{array}$ & $\begin{array}{l}\text { Soil } \\
\text { horizon }\end{array}$ & $\begin{array}{l}\text { Depth } \\
\text { [cm] }\end{array}$ & $\begin{array}{l}\text { Drainage } \\
\text { porosity } \\
{[\% \mathrm{v} / \mathrm{v}]}\end{array}$ & $\begin{array}{l}\mathrm{Ks} \\
{\left[\mu \mathrm{m} \mathrm{s}^{-1}\right]}\end{array}$ & $\begin{array}{l}\text { Classes } \\
\text { of } \mathrm{K}_{\mathrm{s}}\end{array}$ \\
\hline \multirow[t]{4}{*}{1} & M & $0-32$ & 19.3 & 9.2 & $\mathrm{mh}$ \\
\hline & Oa1 & $32-71$ & 6.60 & 4.5 & $\mathrm{mh}$ \\
\hline & $\mathrm{Oa} 2$ & 71-130 & 18.4 & 5.8 & $\mathrm{mh}$ \\
\hline & Cgg & $130-200$ & 30.3 & 52.3 & $\mathrm{~h}$ \\
\hline \multirow[t]{4}{*}{2} & $\mathrm{Au}$ & $0-31$ & 21.1 & 16.2 & $\mathrm{~h}$ \\
\hline & $\mathrm{AC}$ & $31-46$ & 21.4 & 15.1 & $\mathrm{~h}$ \\
\hline & $\mathrm{C} 1$ & $46-67$ & 30.9 & 51.3 & $\mathrm{~h}$ \\
\hline & Cgg2 & 67-150 & 30.5 & 44.6 & $\mathrm{~h}$ \\
\hline \multirow[t]{3}{*}{3} & $\mathrm{M}$ & $0-33$ & 13.8 & 5.5 & $\mathrm{mh}$ \\
\hline & $\mathrm{Oa}$ & 33-135 & 9.40 & 4.9 & $\mathrm{mh}$ \\
\hline & Cgg & $135-200$ & 32.4 & 55.7 & $\mathrm{~h}$ \\
\hline \multirow[t]{4}{*}{4} & M & $0-32$ & 21.8 & 15.8 & $\mathrm{~h}$ \\
\hline & Oa1 & $32-57$ & 10.0 & 6.3 & $\mathrm{mh}$ \\
\hline & $\mathrm{Oa} 2$ & 57-105 & 10.7 & 6.8 & $\mathrm{mh}$ \\
\hline & Cgg & 105-152 & 34.4 & 43.8 & $\mathrm{~h}$ \\
\hline \multirow[t]{4}{*}{5} & M & $0-27$ & 11.8 & 6.4 & $\mathrm{mh}$ \\
\hline & Oa1 & $27-64$ & 8.30 & 7.8 & $\mathrm{mh}$ \\
\hline & $\mathrm{Oa} 2$ & $64-82$ & 19.1 & 8.9 & $\mathrm{mh}$ \\
\hline & Cgg & $82-150$ & 33.7 & 52.4 & $\mathrm{~h}$ \\
\hline \multirow[t]{4}{*}{6} & $\mathrm{Au}$ & $0-43$ & 38.2 & 31.5 & $\mathrm{~h}$ \\
\hline & $\mathrm{C} 1$ & $43-58$ & 32.4 & 41.7 & $\mathrm{~h}$ \\
\hline & Cgg2 & $58-74$ & 13.9 & 5.30 & $\mathrm{mh}$ \\
\hline & Cgg3 & 74-102 & 26.7 & 30.6 & $\mathrm{~h}$ \\
\hline
\end{tabular}

Explanation: mh - moderately high; $\mathrm{h}$ - high

As described above, Ks is an important feature in a group of soil properties that shape the susceptibility of the soils to drainage (Kennedy and Price, 2005; Liu et al., 2016). The abovementioned authors also notice the variability in water permeability of soils, which appear along with progressive drainage. Water permeability in hydrogenic sites can take very different values (e.g. Gnatowski et al., 2010). In the literature, one can find reports on the influence on Ks of properties, such as: peat decomposition degree (Klove, 2000), DP (Quinton et al., 2008), and BD (Boelter, 1969) in organic deposits. Kopp et al. (2013) have suggested that the aforementioned properties have a stronger impact on water permeability in natural habitats, although these relationships are less clearly defined in drained habitats. This opinion is indirectly confirmed by Wallage and Holden (2011) and Holden et al. (2006). In the former study, the authors state that drainage of the peatland caused a decrease in the proportion of macropores, while in the latter study, an increase was observed. In the tested soils, Ks ranged from medium-high to high (Mocek and Drzymała, 2010). In the epipedons, it ranged from 5.5 to $31.5 \mu \mathrm{m} \mathrm{s}^{-1}$ (profiles 3 and 6 ). In peats horizons, it was usually lower and ranged from 4.5 to $8.9 \mu \mathrm{m} \mathrm{s}^{-1}$ (Oa1, profile 1; Oa2, profile 5; Table 3). The observed results are within the ranges given by the authors mentioned above. Water permeability of the mineral substrate was also high. Peat water permeability has been discussed by Rezanezhad et al. (2016), who showed that permeability decreased with depth. The authors suggested that this trend resulted from the changes that occur in drainage porosity of dehydrated peat. They cite studies that show that the upper horizons of hydrogenic habitats are characterised by a pore size structure different to the deeper horizons (Rezanezhad et al., 2010). According to these reports, the upper horizons are dominated by large, interconnected spaces that facilitate the flow of water, a phenomenon also noted by Baird and Waldron (2003). The influence of DP on water permeability was high; Spearman's correlation coefficient was positive and amounted to 0.88 . The effect of OMC on permeability was less pronounced, Spearman's correlation coefficient was negative and amounted to - 0.54 (Table 2). The performed statistical analysis showed that the mineralization of organic matter in the studied soils resulted in an increase in permeability, which is in agreement with the findings of Zeitz and Velty (2002) but in contrast with the work of Zongping et al. (2016).

An important property of hydrogenic habitats (in addition to water permeability) that has a key impact on their functioning 
and on conditions for plant growth and development is the retention capacity of the soils (Michel, 2010). Maximum water capacity (MWC) was usually 1-3\% lower than TP (Table 4). Similar observations have been made by Gajewski et al. (2011). Moisture at field capacity (FC; pF 2.0) was high and ranged from 13.1 to $65.4 \% \mathrm{v} / \mathrm{v}$. in the epipedons (respectively: profiles 6 and 5), and was higher in the peat horizons, where it ranged from 55.4 (Oa, profile 3) to $75.6 \% \mathrm{v} / \mathrm{v}$. (Oa2, profile 4; Table 4). Slightly higher moisture content at this potential has been reported for the peat horizons by Berglund and Berglund (2011). Spearman's correlation coefficient between OMC and FC was positive and amounted to 0.84 (Table 2). High moisture content at the refill point (pF 3.7) was an unfavourable feature of the studied soils from an agricultural point of view (Table 4). In the upper horizons, it ranged from 7.2 (profile 6) to $46.3 \% \mathrm{v} / \mathrm{v}$. (profile 3). In the peat horizons it was usually higher: from 35.9 to $53.4 \% \mathrm{v} / \mathrm{v}$. (Oa, profile 3; Oa2, profile 4). Berglund and Berglund (2011) observed higher moisture content at this potential. Humidity at the wilting point (WP - $\mathrm{pF}$ 4.2) was also very high, and was most often lower in the upper horizons: $3.4-19.4 \% \mathrm{v} / \mathrm{v}$. (respectively: profiles 6 and 1; Table 4) than in the peats underlying them: from 16.1 to $26.1 \%$ v/v. (Oa2, profile 5; Oa2, profile 4). Higher values are provided by Berglund and Berglund (2011), as well as by Gnatowski et al. (2010), who noted the significant differences in the level of this trait between peats of different botanical composition. In their research, moisture content at WP ranged from 17 to $50 \%$ v. Some studies have demonstrated the very high maximum hygroscopic moisture content of peat (Zając et al., 2018). In the cited studies, $\mathrm{MH}$ reached a level of almost $30 \% \mathrm{v}$. In the tested soils, the humidity was lower, and was in the following range: $1.9-7.9 \%$ $\mathrm{v} / \mathrm{v}$. in the epipedons and $10.4-19.6 \% \mathrm{v} / \mathrm{v}$. in the peat horizons (Table 4). The content of strongly bound water (moisture content at RF, WP and MH) was positively correlated with OMC (Table 2). Similar relationships were noted by Monates-Pulido et al. (2017).

Based on the humidity values described above, RAW and TAW values were calculated. In the tested epipedons, the lowest RAW value $(5.9 \% \mathrm{v} / \mathrm{v}$.) was observed in the horizon with the lowest OMC (profile 6; Tables 1 and 4). On the other hand, the highest RAW value $(22.5 \% \mathrm{v} / \mathrm{v}$.) was found in the upper horizon of profile 1 , where OMC was greatest. In the peat horizons, RAW ranged from $17.5 \% \mathrm{v} / \mathrm{v}$. to $22.9 \% \mathrm{v} / \mathrm{v}$. (Oa2, profile 5; Oa1, profile 4; Table 4). Water retention capacities of organic soils were also investigated by Oleszczuk et al. (2018). The research results

Table 4

Soil water potentials of examined soils

\begin{tabular}{|c|c|c|c|c|c|c|c|c|c|}
\hline \multirow{2}{*}{$\begin{array}{l}\text { Soil } \\
\text { profile }\end{array}$} & \multirow{2}{*}{$\begin{array}{l}\text { Soil } \\
\text { horizon }\end{array}$} & \multirow{2}{*}{$\begin{array}{l}\text { Depth } \\
{[\mathrm{cm}]}\end{array}$} & \multicolumn{5}{|c|}{ Moisture at pF [\% v/v] } & \multirow{2}{*}{$\begin{array}{l}\text { RAW } \\
{[\% \mathrm{v} / \mathrm{v}]}\end{array}$} & \multirow{2}{*}{$\begin{array}{l}\text { TAW } \\
{[\% \mathrm{v} / \mathrm{v}]}\end{array}$} \\
\hline & & & 0.0 & 2.0 & 3.7 & 4.2 & 4.5 & & \\
\hline \multirow{2}{*}{1} & Oa1 & $32-71$ & 78.4 & 69.3 & 50.2 & 18.9 & 13.1 & 19.1 & 50.4 \\
\hline & Oa2 & $71-130$ & 73.1 & 62.4 & 44.8 & 18.6 & 14.3 & 17.6 & 43.8 \\
\hline \multirow[t]{3}{*}{2} & $\mathrm{Au}$ & $0-31$ & 60.2 & 40.2 & 20.1 & 5.4 & 2.8 & 20.1 & 34.8 \\
\hline & $\mathrm{AC}$ & $31-46$ & 35.4 & 16.5 & 9.7 & 3.4 & 1.1 & 6.8 & 13.1 \\
\hline & $\mathrm{C} 1$ & $46-67$ & 38.2 & 8.4 & 2.3 & 1.1 & 0.4 & 6.1 & 7.3 \\
\hline & Cgg & $135-200$ & 37.8 & 6.9 & 2.5 & 1.1 & 0.6 & 4.4 & 5.8 \\
\hline \multirow[t]{4}{*}{4} & $\mathrm{M}$ & $0-32$ & 71.2 & 50.9 & 32.4 & 13.5 & 7.4 & 18.5 & 37.4 \\
\hline & Oa1 & $32-57$ & 81.5 & 73.6 & 50.7 & 25.3 & 16.2 & 22.9 & 48.3 \\
\hline & $\mathrm{Oa} 2$ & 57-105 & 84.2 & 75.6 & 53.4 & 26.1 & 19.6 & 22.2 & 49.5 \\
\hline & Cgg & 105-152 & 40.3 & 7.5 & 2.4 & 1.3 & 0.4 & 5.1 & 6.2 \\
\hline \multirow[t]{2}{*}{5} & $\mathrm{M}$ & $0-27$ & 75.6 & 65.4 & 43.7 & 18.6 & 6.5 & 21.7 & 46.8 \\
\hline & Oa1 & $27-64$ & 78.3 & 69.6 & 49.7 & 19.6 & 11.5 & 19.9 & 50.0 \\
\hline 6 & Cgg3 & 74-102 & 33.8 & 8.4 & 5.1 & 2.9 & 1.8 & 3.3 & 5.5 \\
\hline
\end{tabular}

Explanation: RAW - readily available water; TAW - total available water 
cited by them concern the drained sites to a different extent. On their basis, they concluded that the progressive process of moorshing and mineralization of organic matter leads to deterioration of the water retention capacities of organic soils. Similar observations arise from the analysis of the results obtained in the study. Statistical analysis showed a moderate and positive Spearman correlation between OMC and RAW (Table 2). Here, TAW was very high, in some levels more than double the RAW values (Table 4). As in the case of RAW, a positive correlation was found between OMC and TAW (Table 2). Monates-Pulido et al. (2017) reached similar conclusions, while Gnatowski et al. (2010) also drew attention to the high, but also variable levels of TAW in peats.

\section{Conclusions}

The epipedons of all the soils examined in this study exhibited features of the mursh-forming process, which morphologically revealed in the form of a strong granular structure. They were deposited directly on highly decomposed peat or on mineral horizons - usually sands with a single grained structure. While such a morphological structure indicates that the studied soils have already been drained, it does not exclude the possible acceleration and deepening of this process by the commencement of mining activities. This claim is supported by the types of soil water regimes present in the area during the field study period. The murshic and post-murshic formations were usually characterised by greater PD and BD values, and by lower TP values compared to the underlying peat horizons. In comparison to the parent rock material, they were also characterised by greater DP, greater water permeability and had a lower water content available to plants. Such a relationship suggests that the progressive mineralisation of organic matter may significantly affect the agricultural properties of soils, which is critical from an agricultural point of view, and may reduce the productivity of these lands. Given that the possible commencement of opencast mining operations may accelerate and deepen these changes, it is reasonable to conduct systematic tests at the measuring points designated in the study.

\section{References}

Ajibola, Y.H., Oguntunde, P.G., Lawal, K., 2018. Land use effects on soil erodibility and hydraulic conductivity in Akure, Nigeria. African Journal of Agricultural Research 13(7), 329-337. https://doi.org/10.5897/ AJAR2017.12947

Alberski, J., Grzegorczyk, S., Pawluczuk, J., 2012. Warunki siedliskowe fitocenoz ze znaczącym udziałem Deschampsia caespitosa (L.) P. Beauv. w runi użytków zielonych Pojezierza Olsztyńskiego. WodaŚrodowisko-Obszary Wiejskie 12, z. 3 (39), 7-15. (in Polish with English summary).

Baird, A.J., Waldron, S., 2003. Shallow horizontal groundwater flow in peatlands is reduced by bacteriogenic gas production. Geophysical Research Letters 30(20), 2043 pp. https://doi.org/10.1029/ 2003GL018233

Berglund, K., 2008. Torvmarken, en resurs i jordbruket igĺr, idag och även i morgon. In: Runefelt, L. (Ed.), Svensk mosskultur e Odling, torvan- vändning och landskapets förändring. Enheten för de Areella Näringarnas Historia, KSLA, Eskilstuna, 483-498.

Berglund, O., Berglund, K., 2011. Influence of water table level and soil properties on emissions of greenhouse gases from cultivated peat soil. Soil Biology and Biochemistry 43, 923-931. https://doi.org/10.1016/ j.soilbio.2011.01.002

Biemelt, D., Schapp, A., Grünewald, U., 2011. Hydrological observation and modelling relationship for the determination of water budget in Lusatian post-mining landscape. Physics and Chemistry of the Earth 36, 3-18. https://doi.org/10.1016/j.pce.2010.07.015

Blake, G.R., Hartge, K.H., 1986. Particle density. In: Klute A. (Eds.) Methods of soil analysis. Part 1. 2nd ed. Agronomy Monograph 9 ASA and SSSA, Madison, Wi. 377-382.

Boelter, D.H., 1969. Physical properties of peats as related to degree of decomposition. Soil Science Society of America Journal 33, 606-609. https://doi.org/10.2136/sssaj1969.03615995003300040033x

Bruland, G.L., Richardson C.J., 2004. Hydrologic gradients and topsoil additions affect soil properties of Virginia created wetlands. Soil Science Society of America 68, 2069-2077. https://doi.org/10.2136/sssaj2004.2069

Carey, S.K., Quinton, W., Goeller, N.T., 2007. Field and laboratory estimates of pore size properties and hydraulic characteristics for subarctic organic soils. Hydrological Processes 21, 2560-2571. https://doi. org/10.1002/hyp.6795

Gajewski, P., Jakubus, M., Kaczmarek, Z., 2011. Właściwości fizyczne i wodne gleb hydrogenicznych w sąsiedztwie uruchamianej odkrywki węgla brunatnego „Tomisławice”. Roczniki Gleboznawcze - Soil Science Annual 62, 2, 86-94. (in Polish with English abstract).

Glina, B., Bogacz, A., Bojko, O., Kordyjarek, M., 2013. Zróżnicowanie gleb z obszaru torfowiska stokowego okolic Karłowa (Park Narodowy Gór Stołowych). Episteme 18(3), 287-296. (in Polish with English abstract).

Glina, B., Gajewski, P., Kaczmarek, Z., Owczarzak, W., Rybczyński, P., 2016. Current state of peatland soils as an effect of long-term drainage - preliminary results of peatland ecosystems investigation in the Grójecka Valley (central Poland). Roczniki Gleboznawcze - Soil Science Annual 67(1), 3-9. https://doi.org/10.1515/ssa-2016-0001

Glina, B., Gajewski, P., Mendyk, Ł., Zawieja, B., Kaczmarek, Z., 2019. Recent changes in soil properties and carbon stocks in fen peatlands adjacent to open-pit lignite mines. Land Degradation and Development, 30(18), 2371-2380. https://doi.org/10.1002/ldr.3428

Grimshaw, H.M., Allen, S.E., Parkinson, J.A., 1989. Chemical Analysis of Ecological Materials. 2nd. Blackwell Scientific Publications, London, $81 \mathrm{pp}$.

Gnatowski, T., Szatylowicz, J., Brandyk, T., Kechavarzi, C., 2010. Hydraulic properties of fen peat soils in Poland. Geoderma 154, 188-195. https:// doi.org/10.1016/j.geoderma.2009.02.021

Hoag, R.S, Price, J.S., 1997. The effects of matrix diffusion on solute transport and retardation in undisturbed peat in laboratory columns. Journal of Contaminant Hydrology 28, 193-205. https://doi.org/10.1016/ S0169-7722(96)00085-X

Holden, J., Evans, M., Burt, T., Horton, M., 2006. Impact of land drainage on peatland hydrology. Journal of Environmental Quality 35, 5, 1764-1778. https://doi.org/10.2134/jeq2005.0477

Holden, J., Wallage, Z.E., Lane, S.N., McDonald, A.T., 2011. Water table dynamics in undisturbed, drained and restored blanket peat. Journal of Hydrology 402, 103-114. https://doi.org/10.1016/j.jhydrol.2011.03.010

Ilnicki, P., 2002. Torfowiska i torf. Wyd. Akademii Rolniczej im. A. Cieszkowskiego, Poznań, 606 pp (in Polish).

IUSS Working Group WRB, 2015. World Reference Base for Soil Resources 2014, update 2015 International Soil Classification System for Naming Soil and Creating Legends for Soil Maps. World Soil Resources Reports No. 106, FAO, Rome, 190pp.

Jahn, R., Blume, H.P., Asio, V.B., Spaargaren, O., Schad, P., 2006. Guidelines for soil description, FAO, Rome, $97 \mathrm{pp}$. 
Kalisz, B., Łachacz, A, Głażewski, R., 2010. Transformation of some organic matter components in organic soils exposed to drainage. Turkish Journal of Agriculture and Forestry 34(3), 245-256. https://doi. org/10.3906/tar-0905-33

Kalisz, B, Łachacz, A, Głażewski, R., 2015. Effects of peat drainage on labile organic and water repellency in NE Poland. Turkish Journal of Agriculture and Forestry 39, 20-27. http://doi.org/10.3906/tar-1402-66

Kamiński, J., 2007. Rozwój zbiorowisk roślinnych na glebie torfowo-murszowej po zaniechaniu wieloletnich upraw polowych. Woda-Środowisko-Obszary Wiejskie 7, z.2a, (20), 173-189. (in Polish with English summary).

Kechavarzi, C., Dawson, Q., Leeds-Harrison, P.B., 2010. Physical properties of low-lying agriculture peat soils in England. Geoderma 154, 196-202. https://doi.org/10.1016/j.geoderma.2009.08.018

Kellner, E., Halldin, S., 2002. Water budget and surface-layer water storage in a Sphagnum bog in central Sweden. Hydrological Processes 16, 87-103. https://doi.org/10.1002/hyp.286

Kennedy, G.W., Price, J.S., 2005. A conceptual model of volume change controls on the hydrology of cutover peats. Journal of Hydrology 302, 13-27. https://doi.org/10.1016/j.jhydrol.2004.06.024

Klřve, B., 2000. Effect of peat harvesting on peat hydraulic properties and runoff generation. Suoseura 51(3), 121-129.

Klute, A., 1986. Water retention: laboratory methods. In: A. Klute (Eds.) Methods of soil analysis. Part 1. Physical and mineralogical methods. American Society of Agronomy-Soil Science Society of America, Madison, Wisc., 635-662.

Klute, A., Dirksen, C., 1986. Hydraulic conducticity and difusivity: laboratory methods. In: Klute A. (Eds.). Methods of Soil Analysis, Part 1: Physical and Mineralogical Methods. 2nd. Agronomy Monograph 9 ASA and SSSA, Madison, Wi. 687-734.

Kopp, B.J., Fleckenstein, J.H., Roulet, N.T., Humphreys, E., Talbot, J., Blodau, C., 2013. Impact of long-term drainage on summer groundwater flow patterns in the Mer Bleue peatland, Ontario, Canada. Hydrology and Earth System Sciences 17, 3485-3498. http://doi.org/10.5194/hess17-3485-2013

Lipka, K., Zając, E., Hlotov, V., Siejka, Z., 2017. Disappearance rate of a peatland in Dublany near Lviv (Ukraine) drained in 19th century. Mires and Peat 19, 1-15. http://doi.org/10.19189/MaP.2017.0MB.279

Liu, H., Janssen, M., Lennartz, B., 2016. Changes in flow and transport patterns in fen peat following soil degradation. European Journal of Soil Science 67, 763-772. https://doi.org/10.1111/ejss.12380

Lorenz, K., Lal, R., Ehlers, K., 2019. Soil organic carbon stock as an indicator for monitoring land and soil degradation in relation to United Nations' sustainable development goals. Land Degradation and Development 30, 824-838. https://doi.org/10.1002/ldr.3270

Michel, J.C., 2010. The physical properties of peat: a key factor for modern growing media. Mires and Peat 6(2), 1-6.

Mocek A., Drzymała S., 2010. Geneza, analiza i klasyfikacja gleb. Wyd. UP Poznań, 418 pp, (in Polish).

Mocek, A., Owczarzak, W., Kaczmarek, Z., 2004. Evaluation criteria of the different soil degradation in the vicinity of workings of open cast lignite mines situated on the Central Polish Lowland. Acta Agrophysica 51, 131-142.

Montes-Pulido, C.R., Miras, J.J.R., Wery, A.M.S.J., 2017. Estimation of soil organic carbon (SOC) at different soil depths and soil use in the Sumapaz paramo, Cundinamarca-Colombia. Acta Agrnonómica 66(1), 95-101. http://dx.doi.org/10.15446/acag.v66n1.53171

Okruszko, H., 1971. Określenie ciężaru właściwego gleb hydrogenicznych na podstawie zawartości w nich części mineralnych. Wiadomości IMUZ 10(1), 47-54 (in Polish).

Okruszko, H., 1981. Faza decesji w naturalnej ewolucji torfowisk niskich. Zeszyty Naukowe AR Wrocław. Rolnictwo 38(134), 39-47. (in Polish)

Oleszczuk, R., Gnatowski, T., Brandyk, T., 2009. Wilgotność krytyczna gleb torfowych jako kryterium nieodwracalności procesu pęcznienia. Acta Agrophysica 14(2), 403-412. (in Polish with English abstract)
Oleszczuk, R., Zając, E., Hewelke, E., Wawer, K., 2018. Determination of water retention characteristics of organic soils, using the indirect filter-paper method. Acta Scientiarum Polonorum Formatio Circumiectus 17(2), 13-21. http://dx.doi.org/10.15576/ASP.FC/2018.17.2.13

Owczarzak, W., Mocek, A., Kaczmarek, Z., Gajewski, P., 2008. Ocena stopnia degradacji naturalnej i antropogenicznej gleb w obszarze odwadniającego oddziaływania odkrywki węgla brunatnego Drzewce. Roczniki Gleboznawcze - Soil Science Annual 59(2), 177-190. (in Polish with English abstract)

Owczarzak, W., Mocek, A., Kaczmarek, Z., Gajewski, P., Glina B., 2017. Changes of soli water regime types in the area adjacent to the Tomisławice open-cast lignite mine (central Poland). Roczniki Gleboznawcze - Soil Science Annual 68(1), 39-45. https://doi.org/10.1515/ ssa-2017-0005

Owczarzak, W., Mocek, A., Kryszak, A., Kryszak, J., 2018. Uzupełniające badania gleboznawcze terenów wokół o/Drzewce - etap V (expertise of the Polish Society of Soil Science - unpublished material).

Panilas, S., Petalas, C.P., Gemitzi, A., 2008. The possible hydrologic effects of the proposed lignite open-cast mining in Drama lignite field, Greece. Hydrological Processes 22, 1604-1617. https://doi.org/10.1002/ hyp. 6729

Pawluczuk, J., Alberski, J., 2011. Warunki siedliskowe i roślinność użytków zielonych na glebach torfowo-murszowych z terenu Pojezierza Olsztyńskiego. Woda Środowisko Obszary Wiejskie 11, 3, 35, 183-195. (in Polish with English summary)

PTG, 2009. Klasyfikacja uziarnienia gleb i utworów mineralnych - PTG 2008. Roczniki Gleboznawcze - Soil Science Annual 60(2), 5-16.

Quinton, W.L., Hayashi, M., Carey, S.K., 2008. Peat hydraulic conductivity in cold regions and its relation to pore size and geometry. Hydrological Processes 22, 2829-2837. https://doi.org/10.1002/hyp.7027

Redding, T.E., Devito, K.J., 2006. Particle densities of wetland soils in northern Alberta, Canada. Canadian Journal of Soil Science 86, 57-60. https://doi.org/10.4141/S05-061

Rezanezhad, F., Price, J.S., Quinton, W.L., Lennartz, B., Milojevic, T. Van Cappellen, P., 2016. Structure of peat soils and implications for water storage, flow and solute transport: A review update for geochemists. Chemical Geology 429, 75-84. http://dx.doi.org/10.1016/ j.chemgeo.2016.03.010

Rezanezhad, F., Quinton, W.L., Price, J.S., Elliot, T.R., Elrick, D., Shook, K.R., 2010. Influence of pore size and geometry on peat unsaturated hydraulic conductivity computed from 3D computed tomography image analysis. Hydrological Processes 24(21), 2983-2994. https://doi. org/10.1002/hyp.7709

Rühlmann, J., Körschens, M., Graefe, J., 2006. A new approach to calculate the particle density of soils considering properties of the soil organic matter and the mineral matrix. Geoderma 130, 272- 283. https://doi. org/10.1016/j.geoderma.2005.01.024

Rząsa, S., Owczarzak, W., Mocek, A., 1999. Problemy odwodnieniowej degradacji gleb uprawnych w rejonach kopalnictwa odkrywkowego na Niżu Środkowopolskim. Wydawnictwo Akademii Rolniczej w Poznaniu, 394 pp. (in Polish).

Sammel, A., Niedźwiecki, E., Meller, E., 2008. Właściwości fizyczne gleb murszastych Równiny Odrzańsko-Zalewowej. Roczniki Gleboznawcze - Soil Science Annual 59(1), 192-197. (in Polish with English abstract)

Schindler, U., Behrendt, A., Muller, L., 2003. Change of soil hydrological properties of fens as a result of soil development. Journal of Plant Nutrition and Soil Science 166, 357-363. https://doi.org/10.1002/ jpln.200390055

Schwärzel, K., Renger, M., Sauerbrey, R., Wessolek, G., 2002. Soil physical characteristics of peat soils. Journal of Plant Nutrition and Soil Science 165,479-486.https://doi.org/10.1002/1522-2624(200208)165:4\%3C479:: AID-JPLN479\%3E3.0.CO;2-8

Soil Survey Division Staff, 1993. Soil survey manual, Soil Conservation Service. U.S. Department of Agriculture Handbook 18, D.C. Washington, $437 \mathrm{pp}$. 
Spychalski, M., Kaźmierowski, C., Kaczmarek, Z., 2007. Estimation of saturated hydraulic conductivity on the basis of drainage porosity. Electronic Journal of Polish Agriculture University 10, Issue 1.

Systematyka gleb Polski, 2019. Polskie Towarzystwo Gleboznawcze, Komisja Genezy Klasyfikacji i Kartografii Gleb. Wydawnictwo Uniwersytetu Przyrodniczego we Wrocławiu, Polskie Towarzystwo Gleboznawcze, Wrocław-Warszawa, 250 pp. (in Polish)

Turbiak, J., Miatkowski, Z., 2016. Z. Ocena tempa mineralizacji masy organicznej w głęboko odwodnionej glebie torfowo-murszowej na podstawie ubytków masy gleby oraz emisji $\mathrm{CO}_{2}$ Woda-Środowisko-Obszary Wiejskie 16, z. 3(55), 73-85. (in Polish with English summary)

Uzarowicz, Ł., Szafranek, A., Kurbiel, M., 2014. Problemy gleboznawczej klasyfikacji bonitacyjnej gruntów rolnych w zasięgu oddziaływania leja depresyjnego KWB „Bełchatów” Roczniki Gleboznawcze - Soil Science Annual 65(4), 170-179. https://doi.org/10.1515/ssa-2015-0011 (in Polish with English abstract)

Wallage, Z.E., Holden, J., 2011. Near-surface macropore flow and saturated hydraulic conductivity in drained and restored blanket peatlands. Soil Use and Management 27, 247-254. https://doi.org/10.1111/j.14752743.2011.00336.x

Wallor, E., Rosskopf, N., Zeitz, J., 2018. Hydraulic properties of drained and cultivated fen soils part I-Horizon-based evaluation of van Genuchten parameters considering the state of moorsh-forming process. Geoderma 313(1), 69-81. https://doi.org/10.1016/j.geoderma.2017.10.026

Wiesmeier, M., Urbanski, L., Hobley, E., Lang, B., von Lützow, M., Marin-Spiotta, E., Kögel-Knabner, I., 2019. Soil organic carbon storage as a key function of soils - A review of drivers and indicators at various scales. Geoderma 333, 149-162. https://doi.org/10.1016/ j.geoderma.2018.07.026

Zając, E., Zarzycki, J., Ryczek, M., 2018. Degradation of peat surface on an abandoned post-extracted bog and implications for re-vegetation. Applied Ecology and Environmental Research 16(3), 3363-3380. http://dx.doi.org/10.15666/aeer/1603_33633380

Zeitz, J., Velty, S., 2002. Soil properties of drained and rewetted fen soils. Journal of Plant Nutrition and Soil Science 165(5), 618-626. https://doi.org/10.1002/1522-2624(200210)165:5\%3C618::AIDJPLN618\%3E3.0.CO;2-W

Zhang, Y., Schaap, M.G., 2019. Estimation of saturated hydraulic conductivity with pedotransfer functions: A review. Journal of Hydrology 575, 1011-1030. https://doi.org/10.1016/j.jhydrol.2019.05.058

Zongping, R., Liangjun, Z., Bing, W., Shengdong, C., 2016. Soil hydraulic conductivity as affected by vegetation restoration age on the Loess Plateau, China. Journal of Arid Land 8(4), 546-555. https://doi. org/10.1007/s40333-016-0010-2

\section{Wybrane właściwości gleb znajdujących się w zasięgu leja depresji planowanego wyrobiska odkrywki Drzewce (środkowa Polska)}

\section{Słowa kluczowe}

Lej depresji

Degradacja odwodnieniowa

Glebowa materia organiczna

Wyrobisko kopalniane

\begin{abstract}
Streszczenie
Odkrywkowa eksploatacja węgla brunatnego wiąże się z koniecznością odwodnienia złoża. Powstający w rezultacie tych działań lej depresji ma zróżnicowaną powierzchnię i głębokość, a cechy te kształtowane są przede wszystkim przez budowę geologiczną i miąższość nadkładu. Powstające przekształcenia hydrologiczne często są wielkoobszarowe, osiągając niekiedy powierzchnię rzędu kilkuset kilometrów kwadratowych. Na części obszarów objętych zasięgiem leja depresji, może nastąpić degradacja produktywności gleb i związana z nią obniżka plonów, dając podstawę do wypłaty stosowanych odszkodowań dla właścicieli takich terenów. Często konieczną staje się zmiana sposobu użytkowania gruntu - renowacja runi łąkowej, a niekiedy nawet likwidacja użytku zielonego. Celem pracy była ocena stanu wybranych gleb w sąsiedztwie planowanego wyrobiska (Pola B) odkrywki węgla brunatnego Drzewce (środkowa Polska). Wykonano 6 profili w glebach organicznych i mineralno-organicznych. Lokalizację punktów badawczych dobrano, tak aby reprezentowały one gleby, które spełniają kryteria siedlisk narażonych na degradację odwodnieniową. Budowa morfologiczna badanych gleb, jak również poziomy analizowanych właściwości wskazują, że zostały one już odwodnione (wskutek oddziaływania czynników klimatycznych i uprawowych), co jednak nie wyklucza przyspieszenia i pogłębienia tego procesu przez ewentualne rozpoczęcie działalności wydobywczej. W przypadku większości analizowanych cech zauważono wysoką korelację ich wartości z zawartością materii organicznej. Zważywszy na to, że, ewentualne rozpoczęcie działalności odkrywki, może wydatnie przyspieszyć i pogłębić zainicjowane już murszenie, zasadnym jest prowadzenie systematycznych badań w zaproponowanych w pracy punktach pomiarowych.
\end{abstract}

